\title{
The Role of Samalas Mega Volcanic Eruption in European Summer Hydroclimate Change
}

\author{
Bin Liu ${ }^{1}$, Jian Liu ${ }^{1,2,3}, *$, Liang Ning ${ }^{1,3,4,5}$, Weiyi Sun ${ }^{1}$, Mi Yan ${ }^{1,3}$, Chen Zhao ${ }^{6}$, \\ Kefan Chen ${ }^{1}$ and Xiaoqing Wang ${ }^{7}$
}

1 Key Laboratory for Virtual Geographic Environment, Ministry of Education, State Key Laboratory Cultivation Base of Geographical Environment Evolution of Jiangsu Province, Jiangsu Center for Collaborative Innovation in Geographical Information Resource Development and Application, School of Geography, Nanjing Normal University, Nanjing 210023, China; gisliubin@gmail.com (B.L.); ningliangnnu@njnu.edu.cn (L.N.); leosunweiyi@163.com (W.S.); myan@njnu.edu.cn (M.Y.); kefan_chen1995@163.com (K.C.)

2 Jiangsu Provincial Key Laboratory for Numerical Simulation of Large Scale Complex Systems, School of Mathematical Science, Nanjing Normal University, Nanjing 210023, China

3 Open Studio for the Simulation of Ocean-Climate-Isotope, Qingdao National Laboratory for Marine Science and Technology, Qingdao 266237, China

4 Climate System Research Center, Department of Geosciences, University of Massachusetts, Amherst, MA 01003, USA

5 State Key Laboratory of Loess and Quaternary Geology, Institute of Earth Environment, Chinese Academy of Sciences, Xi'an 710061, China

6 Institute of Natural Resources and Environmental Audits, Nanjing Audit University, Nanjing 211815, China; zhaochennj@163.com

7 Hebei Provincial Weather Modification Office, Shijiazhuang 050021, China; xqwangoak@163.com

* Correspondence: jliu@njnu.edu.cn

Received: 17 August 2020; Accepted: 29 October 2020; Published: 2 November 2020

\begin{abstract}
In this study, the role of AD 1258 Samalas mega volcanic eruption in the summer hydroclimate change over Europe and the corresponding mechanisms are investigated through multi-member ensemble climate simulation experiments based on the Community Earth System Model (CESM). The results show that the CESM simulations are consistent with the reconstructed Palmer Drought Severity Index (PDSI) and the historical records of European climate. Europe experiences significant summer cooling in the first three years after the Samalas mega volcanic eruption, peaking at $-3.61{ }^{\circ} \mathrm{C},-4.02{ }^{\circ} \mathrm{C}$, and $-3.21^{\circ} \mathrm{C}$ in year 1 over the whole Europe, Southern Europe, and Northern Europe, respectively. The summer surface air temperature (SAT, ${ }^{\circ} \mathrm{C}$ ) changes over the European continent are mainly due to the direct weakening of shortwave solar radiation induced by volcanic aerosol. The summer precipitation over the European continent shows an obvious dipole distribution characteristic of north-south reverse phase. The precipitation increases up to $0.42 \mathrm{~mm} / \mathrm{d}$ in year 1 over Southern Europe, while it decreases by $-0.28 \mathrm{~mm} / \mathrm{d}$ in year 1 over Northern Europe, respectively. Both simulations and reconstructions show that the centers with the strongest increase in precipitation have always been located in the Balkans and Apennine peninsulas along the Mediterranean coast over Southern Europe, and the centers with the strongest precipitation reduction are mainly located in the British Isles and Scandinavia over northwestern Europe. The negative response of North Atlantic Oscillation (NAO) with significant positive sea level pressure (SLP) anomaly in the north and negative SLP anomaly in the south is excited in summer. The low tropospheric wind anomaly caused by the negative phase of NAO in summer affects the water vapor transport to Europe, resulting in the distribution pattern of summer precipitation in Europe, which is drying in the north and wetting in the south. The knowledge gained from this study is crucial to better understand and predict the potential impacts of single mega volcanic eruption on the future summer hydroclimate change in Europe.
\end{abstract}


Keywords: mega volcanic eruption; hydroclimate change; Europe; Samalas; climate simulation

\section{Introduction}

Volcanic eruption is a major natural cause of interannual to multiannual climate change and has affected human society [1]. Understanding the climate response to volcanic eruptions is important for explaining past climate change [2] and predicting seasonal climate after future volcanic eruptions [3,4]. Especially, the mega volcanic eruption has potentially serious impacts on climate change and ecosystems, needing to attract more attention [5].

The AD 1258 Samalas mega volcanic eruption in Indonesia is the largest sulfur-rich volcanic eruption of the Common Era [5-9]. Sedimentological analyses of the deposits confirm the exceptional scale of this event, which had both an eruption magnitude and a volcanic explosion index of 7 [6]. Previous climate simulations suggested that the Samalas mega volcanic eruption and the following three large sulfur-rich volcanic eruptions in the 13th century triggered the Little Ice Age $[10,11]$. Recent research also showed that if other external forcings and new volcanic disturbances are excluded, it takes almost two decades for the global and hemispheric cooling caused by Samalas mega volcanic eruption to completely disappear [5]. Based on proxy records and historic evidence, previous studies suggested that the Samalas mega volcanic eruption has a great impact on climate and social economy in Europe $[6,7,9,12,13]$. Using historical documents, ice core data, and tree ring records, Guillet et al. [6] reconstructed the spatial and temporal climate response of Samalas volcanic eruption and found that Western Europe experienced strong cooling. The medieval chronicles highlight an unusually cold summer, with continuous rain, accompanied by devastating floods and poor harvests [12]. A large number of medieval European documents, including the 'Monumenta Germaniae Historica,' 'Rerum Britannicarum Medii Aevi Scriptores,' and 'Recueil des historiens des Gaules et de la France,' all reported that the cold, incessant rainfall and unusually high cloudiness in AD 1258 prevented crops and fruits from ripening [6]. The Norman 'Notes of Coutances' recorded: 'There was no summer during summer. The weather was very rainy and cold at harvest time, neither the crop harvest nor the grape harvest were good. Grapes could not reach maturity; they were green, altered and in poor health' [6]. The medieval chronicles in Northern Europe recorded the initial warming in the early winter of AD 1258 after the Samalas eruption, followed by extensive wet and cold climatic conditions in AD 1259, which may have affected crops and contributed to the beginning and severity of famines in some regions of the Northern Hemisphere at that time [7]. Archaeologists determined that the mass burial of thousands of medieval skeletons in London dates back to AD 1258 [14], which may be related to the disturbance in the Northern Hemisphere climate caused by the Samalas mega volcanic eruption [9]. The most serious socio-economic consequences reported at the time of the Samalas mega volcanic eruption came from England, where the famine caused by two consecutive years of poor harvests (AD 1256-1257), high prices, and speculation in AD 1258 may have killed about 15,000 people in London alone [14]. Several sources indicate that in AD 1258 and 1259, parts of Europe (Kingdom of France, Kingdom of England, Holy Roman Empire, Iberian Peninsula) experienced severe food shortages and survival crises [6]. However, the research about the Samalas eruption stated above is mainly based on proxy data and reconstructions. There is currently a lack of research on the response of the European summer climate to the Samalas mega volcanic eruption based on simulation. Further research is needed on the impact mechanisms of Samalas mega volcanic eruption on the European climate.

Large volcanic eruption injects sulfur gases into the stratosphere, which will be converted into sulfate aerosols and cool the surface by blocking the incoming solar radiation, thus affecting the climate changes [15]. In Europe, the response of winter hydroclimate to volcanic eruption resembles a positive phase of the North Atlantic Oscillation (NAO) [16-18]. However, the impact of volcanic eruption on the summer hydrological climate over Europe is not fully understood, especially for the mega volcanic 
eruption, such as Samalas. Reconstruction results show that larger volcanic eruptions are more likely to cause wetting and drying responses in Europe than smaller eruptions [19]. In addition, multi-proxy data show that the climate in Europe at the end of the 20th century and the early 21st century may be warmer than at any period over the past 500 years [20]. Therefore, it is very important to have an in-depth understanding of how stratospheric aerosols generated by the Samalas mega volcanic eruption change the hydrological conditions in Europe and potentially offset warming.

What role does the Samalas mega volcanic eruption play in the summer hydroclimate changes in Europe? What are the differences in the response of the summer climate to the Samalas event in different sub-regions of Europe? What are the mechanisms behind these influences? To address these questions, we carried out multi-member ensemble climate simulation experiments on the AD 1258 Samalas mega volcanic eruption based on Community Earth System Model (CESM). Therefore, we will also offer a more comprehensive understanding of the historical impacts and mechanisms of Samalas mega volcanic eruption on European summer hydroclimate changes from the perspective of simulation research.

The organizational structure of this paper is as follows: Section 2 introduces the model and data. Section 3 shows the detailed response and mechanisms of European summer hydroclimate to Samalas mega volcanic eruption. Section 4 presents the main conclusions and discussion of this study.

\section{Model and Data Description}

\subsection{Model and Experiments}

The fully-coupled Community Earth System Model 1.0.3 (CESM 1.0.3) version T31_g37 (equivalent to $3.75^{\circ} \times 3.75^{\circ}$ ), which was developed by National Center for Atmospheric Research (NCAR), was used to carry out the climate simulation experiments in this study. The model consisted of the Community Atmosphere Model version 4 (CAM4) [21], the Parallel Ocean Program version 2 (POP2) [22], the Community Land Model version 4 (CLM4) [23], and the Sea Ice Model version 4 (CICE4) [24]. The performance of CESM has been verified by numerous previous studies [25-29].

Firstly, we carried out a 2400-year control experiment (CTRL), which used fixed external forcing conditions of AD 1850, with the first 400 years as a spin-up run [27]. Then, the Samalas mega volcanic experiments (VOL), which contained 8-member ensemble simulations with a length of 20 years, that were performed using the 8 different initial conditions adopted from the CTRL. The volcanic forcing was the only changing external forcing in the VOL. Samalas volcanic forcing was added to the 11th model year of each VOL member, i.e., there was no volcanic disturbance in the first 10 model years of VOL, and the 11th model year in VOL was the Samalas mega volcanic eruption year. The volcanic forcing used to drive the VOL in this study was the reconstructed AD 1258 Samalas mega volcanic forcing based on the Ice-core Volcanic Index 2 [30].

In this study, the Samalas mega volcanic eruption was assumed to begin on April 1st. The eruption year and the first year following the Samalas mega volcanic eruption were named year 0 and year 1 , respectively, with the same naming scheme for other years. The summer referred to June-August (JJA) in this study. That means the summer of year 0 referred to the JJA of the eruption year. The anomalies in each VOL experiment were calculated with respect to the 10 years before the Samalas mega volcanic eruption.

\subsection{Reconstruction Data}

The 'Old World Drought Atlas' (OWDA), an annual tree-ring-based June-August reconstruction of self-calibrating Palmer Drought Severity Index (PDSI) over Europe and the Mediterranean Basin during the Common Era [31] was used as the hydrological index to validate the simulated summer hydroclimate changes in Europe. Instead of being based purely on precipitation, the PDSI was based upon a primitive water balance model. The basis of the index was the difference between the amount of precipitation required to retain a normal water-balance level and the amount of actual precipitation [32]. 
The OWDA data used the PDSI unit, which used positive values to indicate wet conditions and negative values to indicate dry conditions.

\section{Results}

\subsection{Summer Hydroclimate Change over Europe after Samalas Mega Volcanic Eruption}

\subsubsection{Comparison of Reconstruction and Simulation}

In order to validate the summer hydroclimate change in the historical period simulated by the CESM, we compared the ensemble mean precipitation simulation results in VOL with the reconstructed OWDA PDSI index (Figure 1). We focused on the ensemble mean results of multi-member simulations when comparing with the reconstructed data. By averaging out the individual simulations, the internal variability was removed, and the impact of Samalas mega volcanic forcing was highlighted, which affects the comparison with reconstructions that are influenced by the combined effects of external forcing and internal variability. However, the magnitude of the Samalas mega volcanic eruption was extremely large, and its impact on the climate was also very strong. Compared with the internal variability, Samalas mega volcanic forcing was likely to dominate the summer hydroclimate changes in Europe after the eruption, at least in the short term. Furthermore, Zanchettin et al. [33] clarified the relative role of forcing uncertainties and initial-condition unknowns in spreading the climate response to volcanic eruptions, and they suggested that forcing uncertainties can overwhelm initial-condition spread in boreal summer. This means that it is relatively reasonable in this study to compare the dry and wet changes in European summer between ensemble mean simulation results and the reconstructed data.

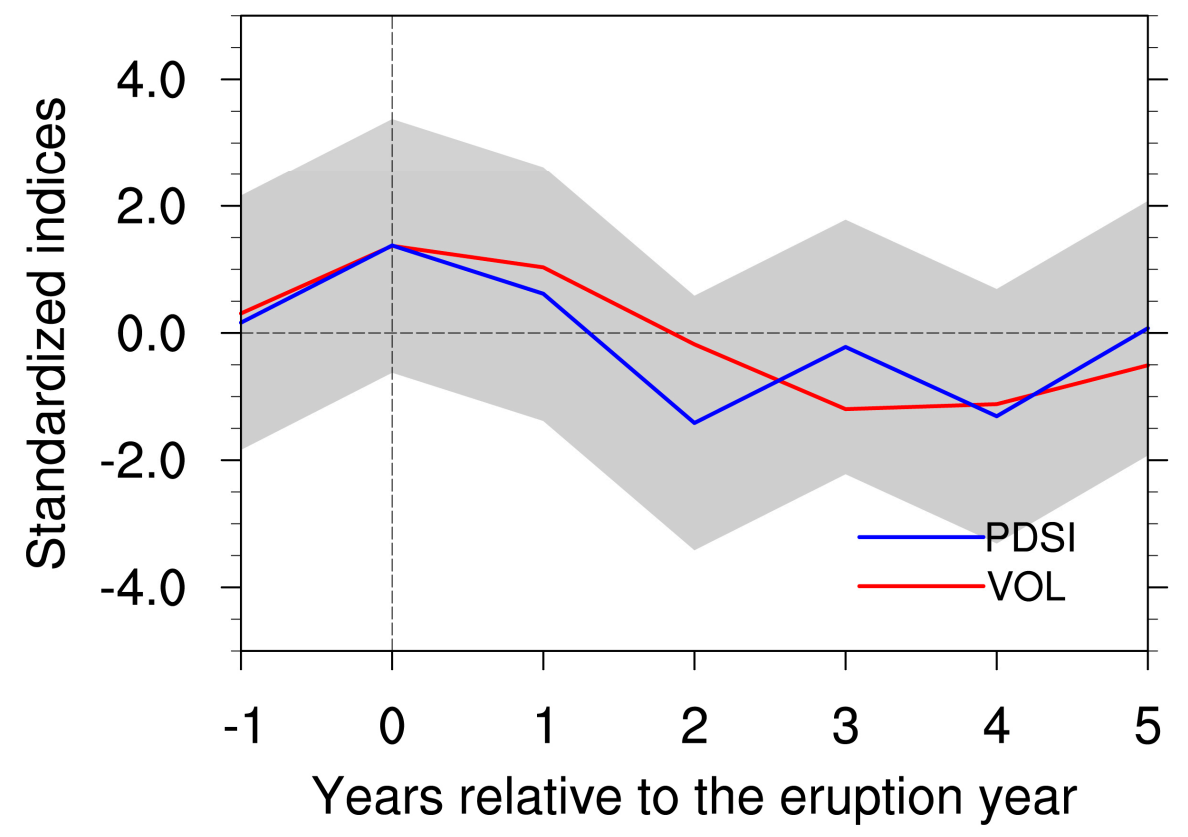

Figure 1. The standardized time series anomalies of reconstructed 'Old World Drought Atlas' (OWDA) Palmer Drought Severity Index (PDSI, blue line) and the simulated summer (JJA) precipitation in volcanic experiments (VOL) (red line). The gray shadow area indicates the uncertainty range of the 2-sigma error of the PDSI reconstruction. The year 0 corresponds to the eruption year. The anomalies are calculated with respect to the 10 years before the Samalas mega volcanic eruption.

The reconstructed JJA OWDA PDSI reflects soil moisture conditions and primarily represents the warm-season hydroclimate over Europe [31]. As a relative index of drought, OWDA PDSI has a high degree of comparability across a broad range of precipitation climatologies [32]. Therefore, the OWDA provides a reconstruction of hydroclimatic variability that allows us to compare the 
simulated hydroclimate variability with the reconstructed dry and wet changes in Europe after Samalas mega volcanic eruption. In this study, we used JJA precipitation changes to represent the simulated summer hydroclimate changes in Europe. Due to the different units between the simulated precipitation and the reconstructed PDSI, we have standardized these two data for the convenience of comparison. As can be seen from Figure 1, after the Samalas mega volcanic eruption, the fluctuation changes of precipitation in VOL and reconstructed PDSI index were relatively consistent. The simulation results were always within the range of two times the standard deviation of PDSI. The correlation coefficient between the standardized JJA precipitation anomaly in VOL and OWDA PDSI was 0.75 (at the 95\% confidence level) over Europe $\left(10^{\circ} \mathrm{W}-40^{\circ} \mathrm{E}, 35^{\circ} \mathrm{N}-70^{\circ} \mathrm{N}\right)$. Both reconstruction and simulations show that the hydrological changes in Europe were humid in the first two years after the Samalas mega volcanic eruption and then turned into drought. CESM has well simulated the dry and wet changes in Europe after the Samalas mega volcanic eruption.

\subsubsection{Summer Precipitation Response to Samalas Mega Volcanic Eruption over Europe}

Figure 2 shows the spatial response of European precipitation after the Samalas mega volcanic eruption in VOL from year 0 to year 2. As can be seen from the ensemble mean results in the VOL (Figure 2), after the Samalas mega volcanic eruption, the summer precipitation over the European continent shows an obvious dipole distribution characteristic of the north-south reverse phase. There was a significant wetting response in year 0 and year 1 over Southern Europe $\left(10^{\circ} \mathrm{W}-40^{\circ} \mathrm{E}\right.$, $35^{\circ} \mathrm{N}-50^{\circ} \mathrm{N}$ ), especially along the Mediterranean coast, while a significant drying response was found over Northern Europe $\left(10^{\circ} \mathrm{W}-40^{\circ} \mathrm{E}, 50^{\circ} \mathrm{N}-70^{\circ} \mathrm{N}\right)$. This spatial pattern of summer precipitation change still existed in year 2 , but it was weakened. This summer precipitation spatial patterns were in agreement with Fischer et al. [34], Wegmann et al. [35], and Gao et al. [19], although their results also showed an averaged summer wetting response in northeast Europe after the tropical eruptions. Judging from the spatial distribution of precipitation anomaly, the wetting in year 0 and year 1 in Southern Europe was significant, especially the precipitation, which increased most in year 1 . Although Northern Europe shows the characteristics of precipitation reduction during year 0-2, the Northern Europe land area only shows significant drought mainly in year 1. Interestingly, after the Samalas mega volcanic eruption, the simulation results of VOL show that the centers with the strongest increase in precipitation have always been located in the Balkans and Apennine peninsulas over Southern Europe, and the centers with the strongest precipitation reduction are mainly located in the British Isles and Scandinavia over northwestern Europe. The results drawn from the VOL simulations are in general agreement with proxy data and reconstructions. Based on seasonal paleoclimate reconstructions, Rao et al. [36] found that wet conditions occur in the eruption year and the following three years in the western Mediterranean. Conversely, northwestern Europe and the British Isles experienced dry conditions in response to volcanic eruptions. This good consistency once again indicates that the simulation results in VOL can well explain the characteristics and causes of summer hydroclimate changes in Europe after the Samalas event recorded in historical documents and reconstructions.

In order to better quantify the summer precipitation response in different European regions to Samalas mega volcanic eruption, we divided Europe into two sub-regions: Southern Europe $\left(10^{\circ} \mathrm{W}-40^{\circ} \mathrm{E}, 35^{\circ} \mathrm{N}-50^{\circ} \mathrm{N}\right)$ and Northern Europe $\left(10^{\circ} \mathrm{W}-40^{\circ} \mathrm{E}, 50^{\circ} \mathrm{N}-70^{\circ} \mathrm{N}\right)$ according to the spatial distribution characteristics of precipitation changes after the Samalas event (Figure 2), and calculated the average precipitation responses of the whole Europe and each sub-region (Figure 3). 
(a) year 0

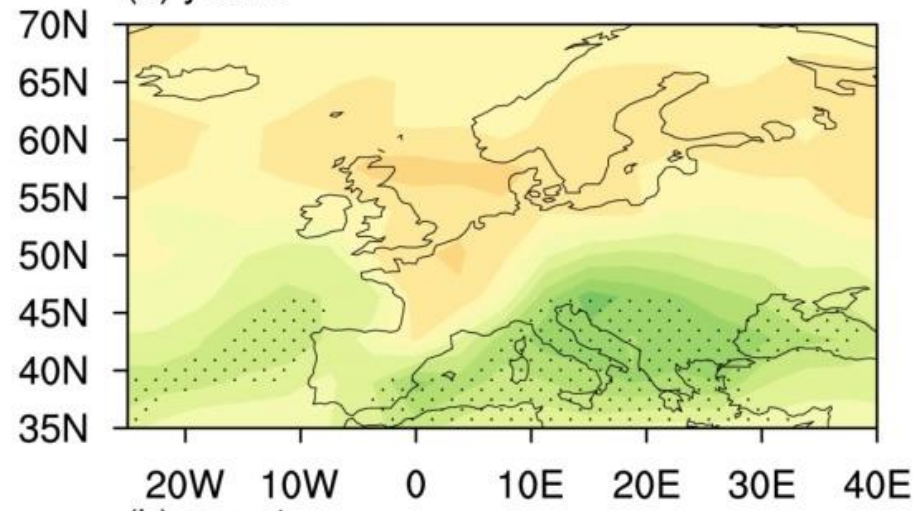

(b) year 1

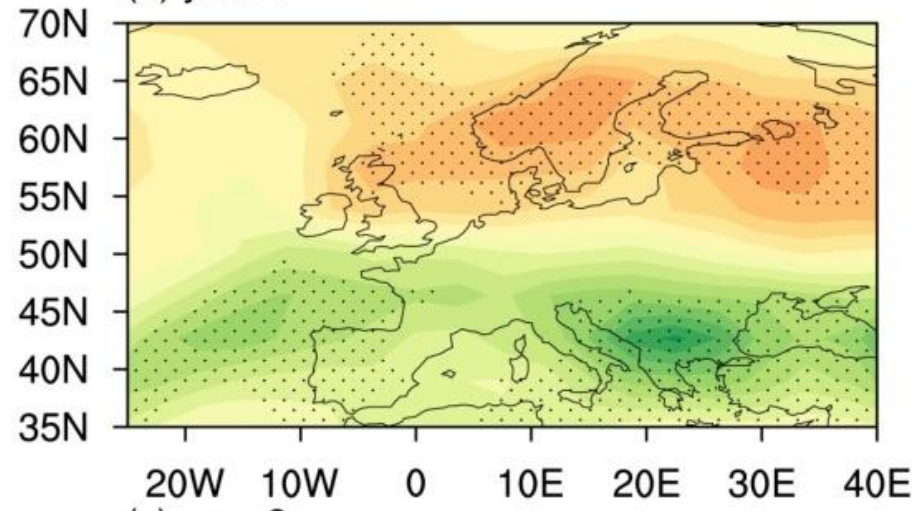

(c) year 2

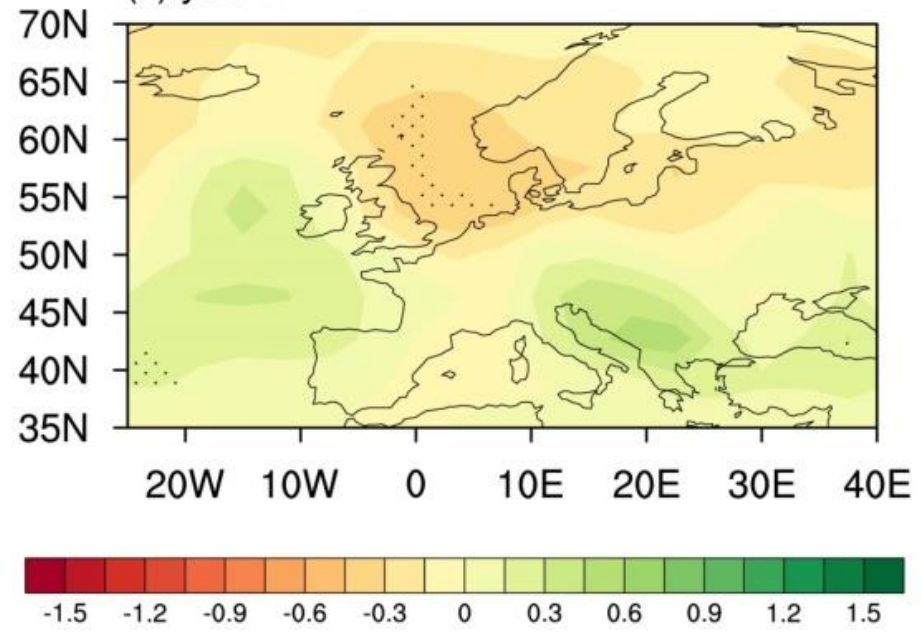

Figure 2. The spatial patterns of European summer (JJA) precipitation (mm/d) anomalies after the Samalas mega volcanic eruption in VOL in (a) year $0,(\mathbf{b})$ year 1 , and (c) year 2 . The dots denote areas with confidence exceeding the $95 \%$ level. The anomalies are calculated with respect to the 10 years before the Samalas mega volcanic eruption. The year 0 corresponds to the eruption year. 

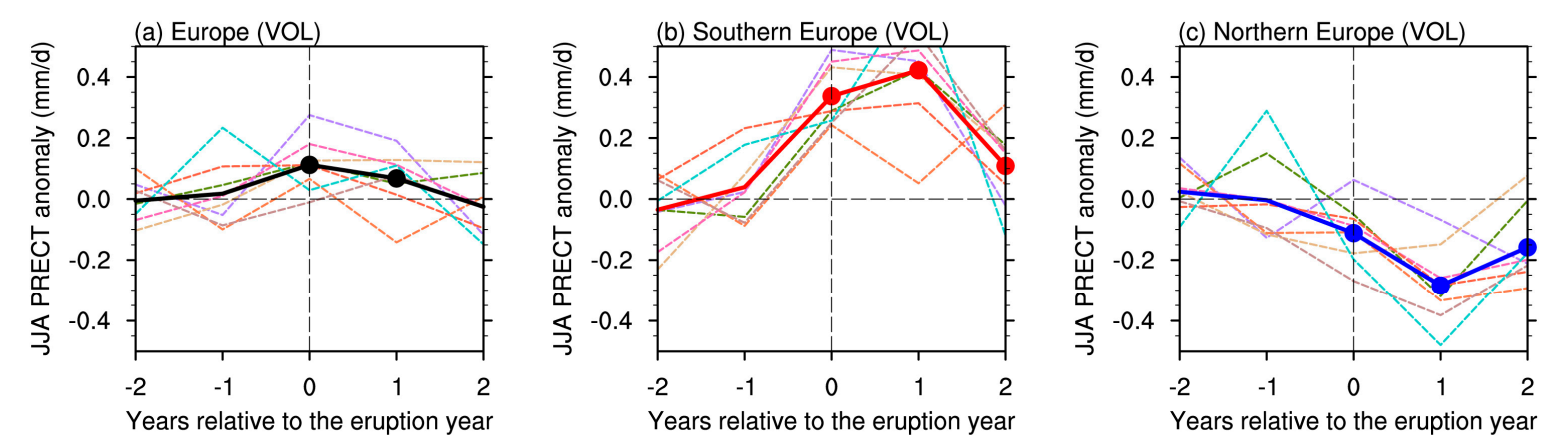

Figure 3. The time series of the summer (JJA) precipitation $(\mathrm{mm} / \mathrm{d})$ anomalies over (a) the whole of Europe, (b) Southern Europe, and (c) Northern Europe in VOL. The black line in (a), red line in (b), and blue line in (c) indicate the ensemble mean results. Other each different colorful line is for one ensemble member. The anomalies are calculated with respect to the 10 years before the Samalas mega volcanic eruption. The black dots in (a), red dots in (b), and blue dots in (c) indicate that the anomalies are significant at a 95\% confidence level based on the Student t-test. Year 0 corresponds to the eruption year.

As shown in the time series in Figure 3, for the whole of Europe, the ensemble mean precipitation increased significantly in year 0 (peaking at $0.11 \mathrm{~mm} / \mathrm{d}$ ) and year 1, reaching the $95 \%$ confidence level, and the European mean precipitation anomaly returned to a normal state in year 2 (Figure 3a). Gao et al. [19] also found similar European precipitation changes after tropical volcanic eruptions using the reconstructed Old World Drought Atlas (OWDA) [31]. After the Samalas mega volcanic eruption, the precipitation in Southern Europe increased significantly (at $95 \%$ confidence level) in the first three years (year 0-2) and peaked with a value of about $0.42 \mathrm{~mm} / \mathrm{d}$ in year 1 (Figure $3 \mathrm{~b}$ ). A large number of medieval European chronicles and documents also reported that the incessant rainfall in $\mathrm{AD} 1258$ prevented crops and fruits from ripening, resulting in severe food shortages and survival crises in AD 1258 and 1259 in parts of Europe such as the Holy Roman Empire and Iberian Peninsula $[6,7,12]$. In contrast, the precipitation in Northern Europe decreased significantly (at 95\% confidence level), especially, the drought was most severe in year 1 with the precipitation anomaly peaking at $-0.28 \mathrm{~mm} / \mathrm{d}$ (Figure 3c). The different precipitation responses of Northern and Southern Europe to Samalas mega volcanic eruption can explain the precipitation changes in the whole of Europe to some extent. In year 0 and year 1, the overall wetting in the whole of Europe was due to the fact that the significant precipitation increase in Southern Europe was stronger than the precipitation decrease in Northern Europe, which dominated the increase of precipitation in the whole of Europe in time series. However, the precipitation increase in Southern Europe was almost equivalent to the precipitation decrease in Northern Europe in year 2, which made the change of spatial average precipitation in the whole of Europe less obvious.

\subsubsection{Summer Temperature Response to Samalas Mega Volcanic Eruption over Europe}

The ensemble mean changes of summer surface air temperature $\left(\mathrm{SAT},{ }^{\circ} \mathrm{C}\right)$ anomaly after the Samalas mega volcanic eruption in VOL are shown in Figure 4. Europe experienced significant cooling in the first three years (year 0-2) after the Samalas eruption (Figure 4a-c). These results were in agreement with Fischer et al. [34], who analyzed the European summer climatic signal following 15 major tropical volcanic eruptions over the last 500 years based on multi-proxy reconstructions, and suggested that the average influence of 15 major volcanic eruptions was a significant European continental scale summer cooling during the first and second post-eruption years. The strongest and highly significant cooling signal was found in the summer of year 1 after the eruption (Figure $4 \mathrm{~b}$ ). Spatially, the sharp cooling response was concentrated in Southern Europe, which was significantly stronger than in Northern Europe in year 0. Then, the entire European land area experienced a sharp drop in temperature in year 1. In the summer of year 2, the cooling over the European continent was 
still significant, but it was obviously weaker than before, and the areas with the significant cooling retreated to the interior of Eastern Europe.

\section{(a) year 0}

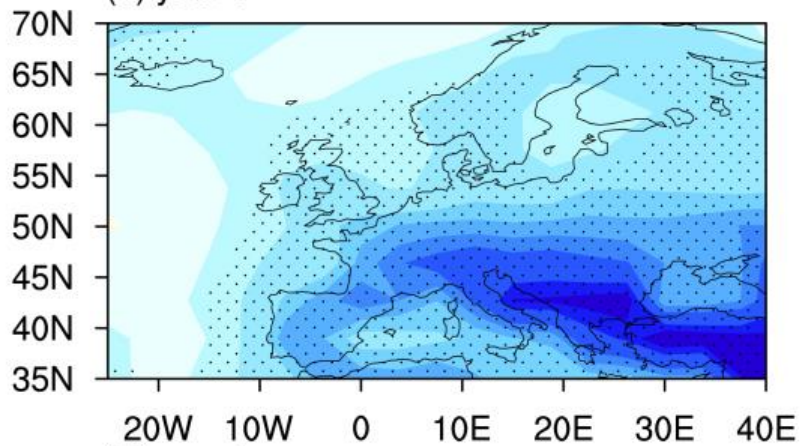

(b) year 1

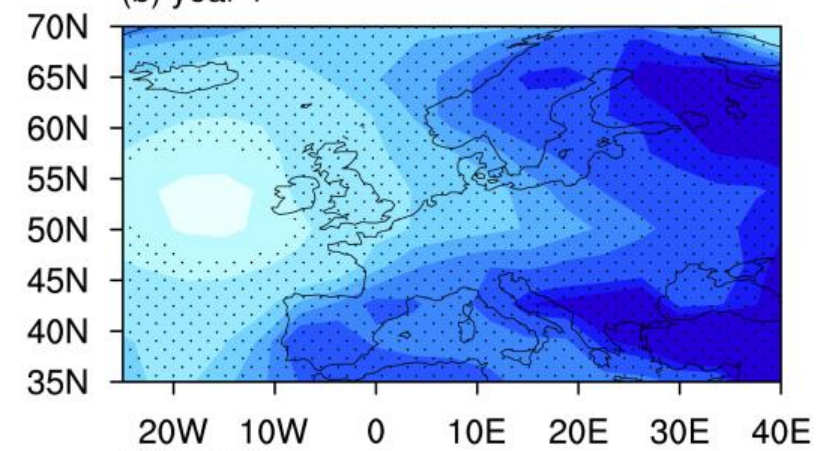

(c) year 2

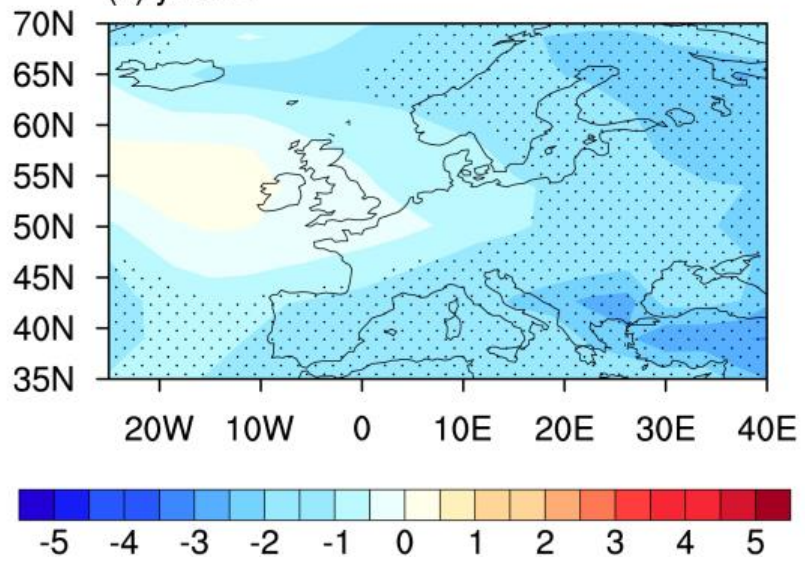

Figure 4. The spatial patterns of ensemble mean European summer (JJA) surface air temperature (SAT, ${ }^{\circ} \mathrm{C}$ ) anomalies after the Samalas mega volcanic eruption in VOL in (a) year 0, (b) year 1, and (c) year 2. The dots denote areas with confidence exceeding the $95 \%$ level. The anomalies are calculated with respect to the 10 years before the Samalas mega volcanic eruption. The year 0 corresponds to the eruption year.

The time series of summer SAT anomaly over the whole of Europe, Southern Europe, and Northern Europe are shown in Figure 5. The whole of Europe and each sub-region show similar SAT variations, with significant cooling anomaly (at 95\% confidence level) in the first three years after the Samalas eruption (Figure $5 \mathrm{a}-\mathrm{c}$ ). For the whole of Europe (Figure 5a), the summer cooling peaks during the eruption year and the first year after the eruption, which was in agreement with the European summer temperature response to the strong tropical volcanic events over the last millennium reported by Luterbacher et al. [37] using the Paleo Model Intercomparison Project Phase 3 (PMIP3) climate model simulations. The largest significant SAT reduction appears in year 1 over the whole of Europe, Southern 
Europe, and Northern Europe with values of $-3.61{ }^{\circ} \mathrm{C},-4.02{ }^{\circ} \mathrm{C}$, and $-3.21^{\circ} \mathrm{C}$, respectively. From year 0 to year 2, the cooling in Southern Europe has always been stronger than that in Northern Europe. Based on historical documents, ice core data, and tree ring records, previous studies also found that Europe experienced an unusually cold summer after the Samalas mega volcanic eruption $[6,7,12]$.
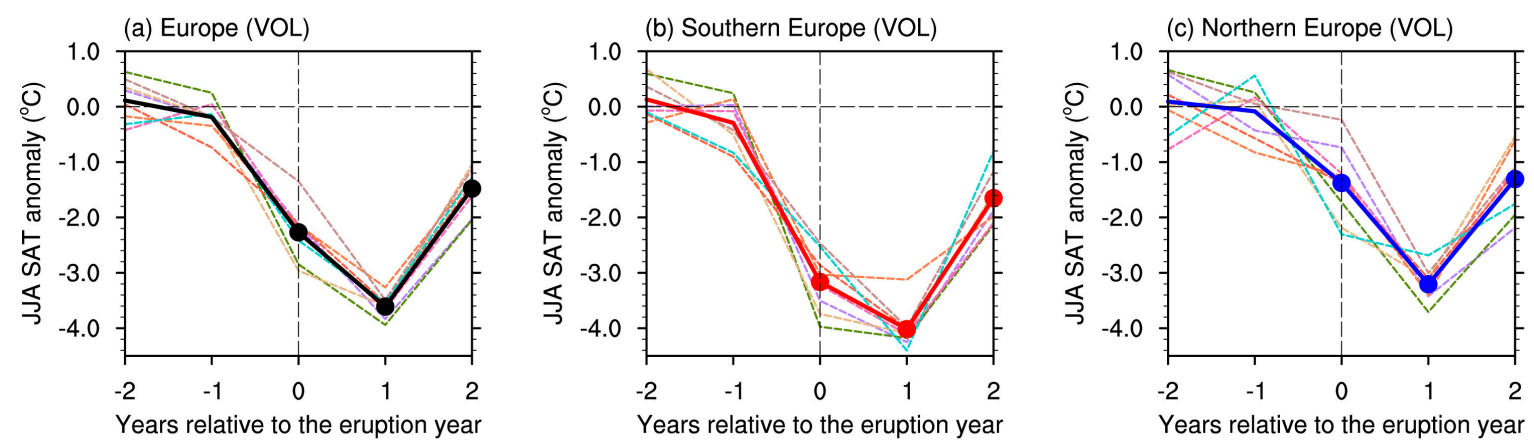

Figure 5. The time series of the summer (JJA) surface air temperature (SAT, ${ }^{\circ} \mathrm{C}$ ) anomalies over (a) the whole of Europe, (b) Southern Europe, and (c) Northern Europe in VOL. The black line in (a), red line in (b), and blue line in (c) indicate the ensemble mean results. Other each different colorful line is for one ensemble member. The anomalies are calculated with respect to the 10 years before the Samalas mega volcanic eruption. The black dots in (a), red dots in (b), and blue dots in (c) indicate that the anomalies are significant at a $95 \%$ confidence level based on the Student $t$-test. The year 0 corresponds to the eruption year.

\subsection{Mechanisms of European Summer Hydroclimate Changes after the Samalas Mega Volcanic Eruption}

The surface heat flux was analyzed to understand the mechanisms underlying the response of the European summer hydroclimate changes to the Samalas mega volcanic eruption. The ensemble means of surface net shortwave flux (FSNS), surface net longwave flux (FLNS), surface sensible heat flux (SHFLX), and surface latent heat flux (LHFLX) in VOL are shown in Figure 6. The surface net shortwave radiation over the European land area decreased significantly, with values of $-27.62 \mathrm{~W} / \mathrm{m}^{2}$, $-19.57 \mathrm{~W} / \mathrm{m}^{2}$, and $-0.58 \mathrm{~W} / \mathrm{m}^{2}$ in year 0 , year 1 , and year 2, respectively (Figure 6a-c). The spatial pattern variation of shortwave radiation was similar to that of temperature. The FSNS decrease in Southern Europe was larger than that in Northern Europe in year 0, and it was significantly reduced in both Southern Europe and Northern Europe in year 1. Then, the FSNS decrease was weakened and retreated to Eastern Europe in year 2. The pattern correlation coefficients between the SAT (Figure 4) and FSNS (Figure 6a-c) are 0.94, 0.86, and 0.39, respectively, in year 0, year 1, and year 2 over the European land area. This suggests that the summer SAT changes over the European continent are largely due to the release of a large amount of sulfur dioxide into the stratosphere and its conversion into sulfate aerosol after the eruption. Volcanic aerosols weaken the shortwave solar radiation reaching the surface in a short period of time, resulting in a significant decrease in the net shortwave radiation on the surface of the European land area, which lasts for 2-3 years (Figure 6a-c). The decrease of solar radiation directly leads to the drop in temperature in year 0-2. Compared with shortwave radiation, the reduction of surface net longwave radiation (Figure $6 \mathrm{~d}-\mathrm{f}$ ) over the European continent was much weaker, with a reduction of $-4.74 \mathrm{~W} / \mathrm{m}^{2},-2.56 \mathrm{~W} / \mathrm{m}^{2}$, and $1.30 \mathrm{~W} / \mathrm{m}^{2}$ in year 0 , year 1 , and year 2 , respectively, after the Samalas mega volcanic eruption. 


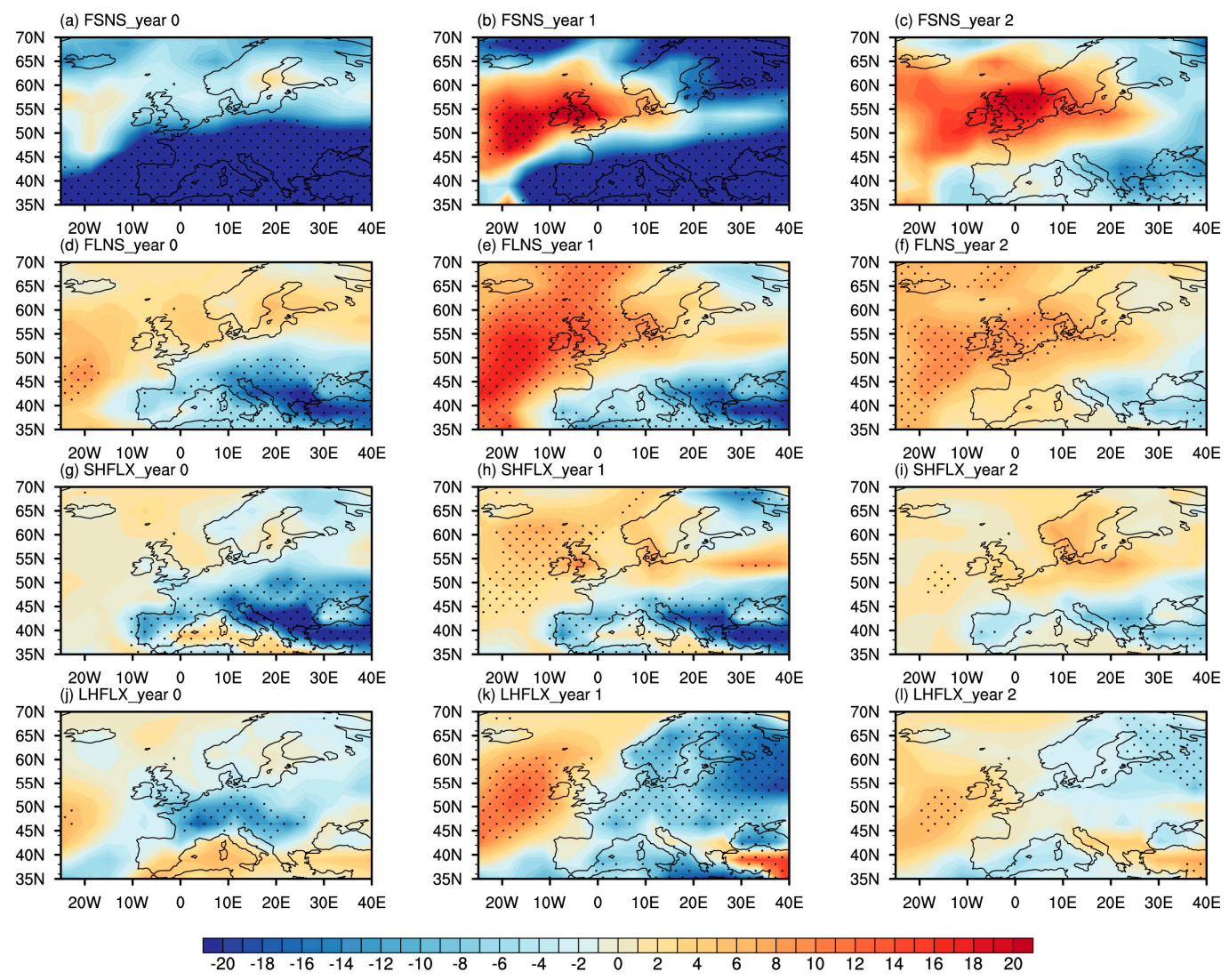

Figure 6. The spatial patterns of ensemble mean $(\mathbf{a}-\mathbf{c})$ surface net shortwave flux (FSNS, W/m²), (d-f) surface net longwave flux (FLNS, W/m²), (g-i) surface sensible heat flux (SHFLX, W/m²) and $(\mathbf{j}-\mathbf{l})$ surface latent heat flux (LHFLX, W/ $\mathrm{m}^{2}$ ) anomalies in summer (JJA) over Europe after the Samalas mega volcanic eruption in VOL from year 0 to year 2 . The dots denote areas with confidence exceeding the $95 \%$ level. The anomalies are calculated with respect to the 10 years before the Samalas mega volcanic eruption. The year 0 corresponds to the eruption year.

Following the mega volcanic eruption of Samalas, the sensible heat flux (Figure $6 \mathrm{~g}-\mathrm{i}$ ) over the European land area mainly decreased, especially over Southern Europe, but did not decrease over the Atlantic Ocean, which indicates that the decrease of SAT on the land is larger than that on the Atlantic Ocean, thus leading to the decrease of the land-sea thermal contrast. From year 1 to year 2, SHFLX continued to decrease in Southern Europe, while it gradually showed a slight increase in Northern Europe (Figure $6 \mathrm{~h}, \mathrm{i}$ ). This may be the potential reason for the spatial difference between the summer precipitation increase in Southern Europe and the precipitation decrease in Northern Europe after the Samalas volcanic eruption. Using a range of climate modeling results, Myhre et al. [38] also pointed out that over the historical period, the sensible heat at the surface was gradually reduced in the CMIP5 models, and hence contributes to an increase in precipitation. Furthermore, the increase in surface latent heat flux (Figure 6j-1) over the North Atlantic region along the European coast, especially in year 1 and year 2, indicated an increase in Atlantic evaporation, which may lead to an increase in precipitation in Southern Europe.

Figure 7 shows the sea level pressure (SLP) anomalies in summer after the Samalas mega volcanic eruption. The ensemble mean result shows a dipole-type response, with significant positive pressure anomaly in the north and negative pressure anomaly in the south. This is an obvious negative phase of NAO. These anomalies are similar to the negative tropospheric Arctic Oscillation pattern in late winter and early spring after the Laki eruption found in Zambri et al. [39], which was manifested as an equatorward shift of the mid-latitude tropospheric jet. NAO is a large-scale meridional oscillation of atmospheric mass between the subtropical high-pressure system near the Azores and the subpolar 
low-pressure system near Iceland [40]. It is widely considered to be the most important mid-latitude source of temperature and precipitation changes over Europe [41,42]. Previous studies [16-18,34] have shown that a positive phase of NAO in boreal winter will be excited after the large tropical volcanic eruption. Here, our results further show that NAO's negative response to the large tropical eruption in summer is totally different from that in winter. Based on extratropical North Atlantic-European mean sea level pressure anomalies for 1881-2003, Folland et al. [43] proposed the summertime parallel of the winter NAO known as the summer North Atlantic Oscillation (SNAO). This SNAO is defined as the first empirical orthogonal function (EOF) of observed summertime extratropical North Atlantic pressure at mean sea level and has a smaller spatial extent than the winter NAO and is located farther north [43]. Compared with Folland et al. [43], we found that the SLP anomalies in summer after the Samalas mega volcanic eruption was more like the typical definition of NAO-like negative phase, which shows that the meridional pressure gradient between Iceland and the Azores was weakened in summer (Figure 7). In addition, during year 1-year 2, this summer NAO negative phase gradually coincided with the SNAO negative phase pattern in Folland et al. [43] (Figure 7). Although the low-pressure center of the summer NAO was located further south in our results (Figure 7), this may be due to the fact that the short-term impact intensity and spatial scale of the external forcing of Samalas mega volcanic eruption on summer NAO were much greater than the impact of the gradual increase of greenhouse gases. Combining reconstructions with ECHAM5.4 simulation results, Wegmann et al. [35] also found that volcanic-induced cooling leads the summer NAO toward a negative phase, which causes the southward movement of the storm track and enhances moisture advection toward southern Europe. In addition, the model simulated summer NAO in Wegmann et al. [35] was also located further south than the SNAO suggested by Folland et al. [43].

To further investigate the relationship between the summer hydroclimate over Europe and the circulation changes, the $850-\mathrm{hPa}$ wind patterns associated with the negative NAO phase are also analyzed as shown in Figure 7 (vector). In the eruption year (year 0), the 850-hPa wind anomalies are characterized by a strong cyclone over the Balkans and Apennine peninsulas near the Mediterranean Sea (Figure 7a). Southwesterly airflow in the lower troposphere transports a large amount of warm and moist air from the Mediterranean to the Balkans, which is conducive to precipitation and makes Southern Europe near the Balkans form a precipitation increase center in year 0. There is also a cyclonic circulation over the Atlantic Ocean, but its location is to the west, which transports less warm and wet Atlantic air to the Iberian Peninsula in southwest Europe (Figure 7a). At the same time, Northern Europe is controlled by a high-pressure anticyclone, resulting in the cold polar air to be blocked by the high pressure and brought to northern and central Europe, while warm air from the south cannot be transported to Northern Europe, which is not conducive to precipitation (Figure 7a). In year 1, the surface latent heat flux over the Atlantic Ocean increases (Figure 6k), indicating an increase in evaporation. At the same time, a strong low-pressure cyclonic circulation over the Atlantic Ocean extends eastward to the land area of Southern Europe, and southwest wind anomalies prevail in Southern Europe (Figure 7b). This circulation change helps to transport a large amount of warm and moist air from the Atlantic Ocean to the Iberian Peninsula in southwest Europe and more moist air from the Mediterranean Sea to the Balkans and Apennine peninsulas, resulting in a significant increase in precipitation throughout Southern Europe. In addition, as can be seen from Figure $7 \mathrm{~b}$, the southwest wind anomaly in the Mediterranean is stronger than that in the Atlantic Ocean, indicating that the Mediterranean Sea may be a more important source of water vapor for the increase of summer precipitation in Southern Europe than the Atlantic Ocean after the Samalas mega volcanic eruption. During the same period, Northern Europe is controlled by a strong high-pressure anticyclone, with anomalous strong northerly winds, and warm air could not be transported northward to Northern Europe, resulting in a significant reduction in precipitation there. In year 2, Southern Europe is basically controlled by low pressure, and the high pressure over Northern Europe weakens (Figure 7c). The circulation anomalies in year 2 is similar to that in year 1 , however, the northerly winds 
over Northern Europe and the southerly winds over Southern Europe are both weakened (Figure 7c), which contributes to the weakening of drought in Northern Europe and wetness in Southern Europe.

\section{(a) year 0}
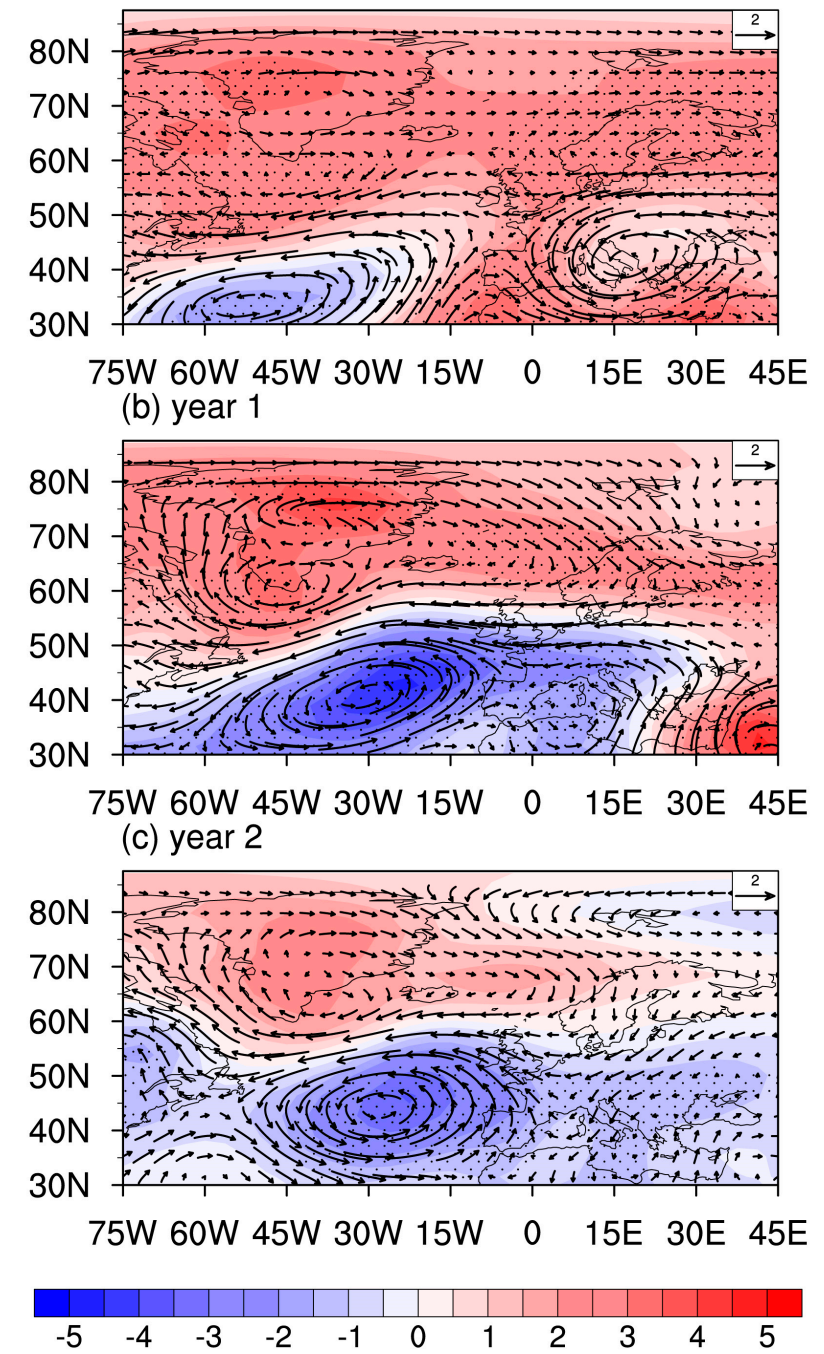

Figure 7. The spatial patterns of the ensemble mean sea level pressure (SLP, hPa, color shading) anomalies and 850-hPa wind (m/s, vector) anomalies in summer (JJA) after the Samalas mega volcanic eruption in VOL in (a) year 0 , (b) year 1 , and (c) year 2 . The dots denote areas with confidence exceeding the $95 \%$ level. The anomalies are calculated with respect to the 10 years before the Samalas mega volcanic eruption. The year 0 corresponds to the eruption year.

Sufficient water vapor supply provides favorable conditions for continuous precipitation. The spatial patterns of the ensemble mean vertically integrated whole-level water vapor transport and its divergence in summer are shown in Figure 8. After the Samalas mega volcanic eruption, the anomalous convergence center was mainly distributed in Southern Europe, especially over the Balkans and Apennine peninsulas (Figure 8). Anomalous southerlies over the east of this convergence center enhanced the northward transport of water vapor to Southern Europe, increasing precipitation there (Figure 8). Anomalous southerlies from the Mediterranean carry more water vapor into Southern Europe. Comparatively speaking, the water vapor transported from the Atlantic Ocean to the Iberian Peninsula is not as strong as that in the Mediterranean Sea (Figure 8). In addition, Northern Europe is dominated by easterlies from the inland, and the anomalous divergence center is mainly distributed over this region, which suppresses precipitation there (Figure 8). 
(a) year 0

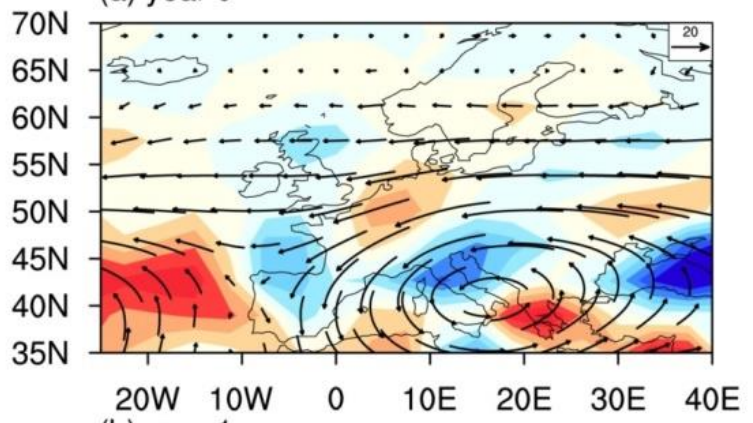

(b) year 1
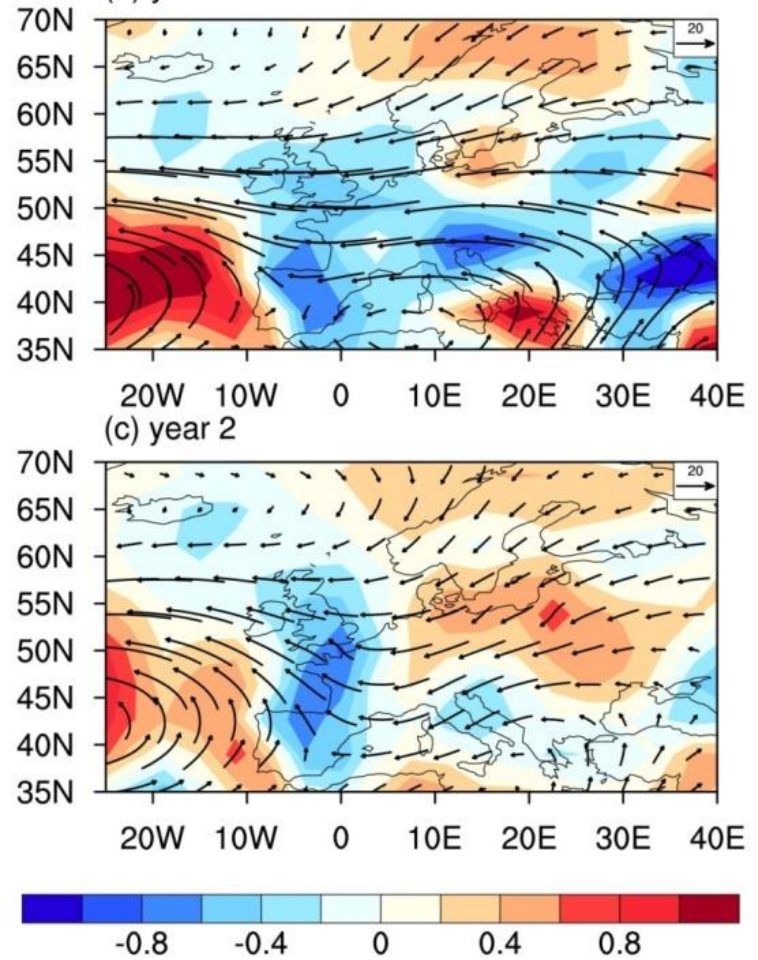

Figure 8. The spatial patterns of the ensemble mean vertically integrated whole-level water vapor transport (100 kg/m/s, vector) anomalies and its divergence $\left(10^{-5} \mathrm{~kg} / \mathrm{m}^{2} / \mathrm{s}\right.$, color shading) anomalies in summer (JJA) after the Samalas mega volcanic eruption in VOL in (a) year 0, (b) year 1, and (c) year 2. The anomalies are calculated with respect to the 10 years before the Samalas mega volcanic eruption. The year 0 corresponds to the eruption year.

\section{Conclusions and Discussion}

In this study, the CESM multi-member ensemble climate simulations are used to analyze the role of AD 1258 Samalas mega volcanic eruption in the summer hydroclimate change over Europe and understand the corresponding mechanisms behind that, which intends to provide a more comprehensive understanding of the historical impact of Samalas mega volcanic eruption on the summer hydroclimate change in Europe from the perspective of simulation research. The major findings are as follows.

Both the reconstructed OWDA PDSI index and our simulations show that the hydrological changes in Europe were humid in the first two years after the Samalas mega volcanic eruption and then turned into drought. CESM has well simulated the dry and wet changes in Europe after the Samalas eruption.

The whole Europe and each sub-region experience significant summer cooling in the first three years (year 0-2) after the Samalas eruption. The largest significant SAT reduction appears in year 1 over the whole Europe, Southern Europe, and Northern Europe with values of $-3.61{ }^{\circ} \mathrm{C},-4.02{ }^{\circ} \mathrm{C}$, 
and $-3.21^{\circ} \mathrm{C}$, respectively. Previous reconstruction studies also found that Europe experienced an unusually cold summer after the Samalas mega volcanic eruption. The summer SAT changes over the European continent after the Samalas eruption is mainly due to the direct weakening of shortwave solar radiation-induced by Samalas volcanic aerosol.

After the Samalas mega volcanic eruption, the summer precipitation over the European continent shows an obvious dipole distribution characteristic of the north-south reverse phase. The precipitation increases up to $0.42 \mathrm{~mm} / \mathrm{d}$ in year 1 over Southern Europe, while it decreases by $-0.28 \mathrm{~mm} / \mathrm{d}$ in year 1 over Northern Europe. Both simulations and reconstructions show that the centers with the strongest increase in precipitation have always been located in the Balkans and Apennine peninsulas along the Mediterranean coast over Southern Europe, and the centers with the strongest precipitation reduction are mainly located in the British Isles and Scandinavia over northwestern Europe. Medieval European chronicles and documents also reported that the incessant rainfall in AD 1258 prevented crops and fruits from ripening, resulting in severe food shortages and survival crises in AD 1258 and 1259 in Southern Europe, such as Holy Roman Empire and Iberian Peninsula.

The negative response of NAO with significant positive SLP anomaly in the north and negative SLP anomaly in the south is excited in summer after the Samalas mega volcanic eruption. The low tropospheric wind anomaly caused by the negative phase of NAO in summer affects the warm and moist air transport to Europe, resulting in the distribution pattern of summer precipitation in Europe, which is drying in the north and wetting in the south. Although the overall precipitation in Southern Europe increases after the Samalas mega volcanic eruption, humid summer in the Balkans and Apennine peninsulas are easier to maintain than those in the Iberian Peninsula over southwest Europe. Precipitation in southwest and southeast Europe comes from different sources of water vapor. Southwest Europe is due to anomalous southwesterlies that transport water vapor from the Atlantic Ocean to the land, while southeast Europe benefits from a steady supply of water vapor from the Mediterranean Sea. This implies that after the Samalas mega volcanic eruption, the Mediterranean Sea may be a more important source of water vapor for the increase of summer precipitation over Southern Europe than the Atlantic Ocean.

In addition to the influence of summer NAO changes after the Samalas mega volcanic eruption, the hydroclimate response in Europe may be further complicated by the other influences of various modes of climate variability, such as the East Atlantic Pattern (EAP) and winter NAO teleconnection. Rao et al. [36] suggested that the impacts of volcanic eruption on spring-summer European hydroclimate are likely modulated by predisposing the EAP toward its negative phase. While the mechanisms for this are still uncertain, one possibility examined in model simulations suggests that its causes may originate in the tropics [36]. The role of these other variability modes in the summer hydroclimate changes in Europe after a single mega volcanic eruption (such as Samalas magnitude) will require further study.

At present, little attention is paid to the summer hydroclimate change in Europe after the single mega volcanic eruption, especially the non-uniform precipitation changes between different sub-regions of Europe. Our results suggest that a single mega volcanic eruption (such as Samalas magnitude) can significantly change the summer hydroclimate in Europe. The knowledge gained from this research is crucial to better understand and predict the potential impacts of single mega volcanic eruption on future European summer hydroclimate changes. Our study has referenced significance for the implementation of stratospheric geoengineering in Europe.

Author Contributions: Conceptualization, B.L. and J.L.; methodology, B.L., J.L. and W.S.; software, J.L. and L.N.; validation, B.L., J.L., L.N., W.S., M.Y., C.Z., K.C., and X.W.; formal analysis, B.L., J.L., and C.Z.; investigation, B.L. and J.L.; resources, J.L.; data curation, J.L., L.N. and M.Y.; writing一original draft preparation, B.L. and J.L.; writing-review and editing, all; visualization, B.L. and C.Z.; supervision, J.L. and L.N.; project administration, J.L.; funding acquisition, J.L. All authors have read and agreed to the published version of the manuscript.

Funding: This research was funded by "National Natural Science Foundation of China", grant number 41971108; "National Key Research and Development Program of China", grant number 2016YFA0600401; "Priority Academic Program Development of Jiangsu Higher Education Institutions", grant number 164320H116; "Postgraduate 
Research \& Practice Innovation Program of Jiangsu Province”, grant number KYZZ16_0456; “Jiangsu Center for Collaborative Innovation in Geographical Information Resource Development and Application".

Acknowledgments: We thank two anonymous reviewers and editor for their valuable comments and suggestions. This research is jointly supported by the National Natural Science Foundation of China (Grant No. 41971108), the National Key Research and Development Program of China (Grant No. 2016YFA0600401), the Priority Academic Program Development of Jiangsu Higher Education Institutions (Grant No. 164320H116), the Postgraduate Research \& Practice Innovation Program of Jiangsu Province (Grant No. KYZZ16_0456), and the Jiangsu Center for Collaborative Innovation in Geographical Information Resource Development and Application. Bin Liu acknowledges China Scholarship Council (201606860006) for the financial support. The reconstructed Samalas volcanic forcing was kindly provided by Chaochao Gao. The reconstructed Palmer Drought Severity Index was kindly provided by Edward R. Cook.

Conflicts of Interest: The authors declare no conflict of interest.

\section{References}

1. Timmreck, C. Modeling the climatic effects of large explosive volcanic eruptions. WIREs Clim. Chang. 2012, 3, 545-564. [CrossRef]

2. Hegerl, G.; Luterbacher, J.; González-Rouco, F.; Tett, S.F.B.; Crowley, T.; Xoplaki, E. Influence of human and natural forcing on European seasonal temperatures. Nat. Geosci. 2011, 4, 99-103. [CrossRef]

3. Trenberth, K.E.; Dai, A. Effects of Mount Pinatubo volcanic eruption on the hydrological cycle as an analog of geoengineering. Geophys. Res. Lett. 2007, 34, L15702. [CrossRef]

4. Robock, A.; Oman, L.; Stenchikov, G.L. Regional climate responses to geoengineering with tropical and Arctic SO2 injections. J. Geophys. Res. Atmos. 2008, 113, D16101. [CrossRef]

5. Liu, B.; Wang, B.; Liu, J.; Chen, D.; Ning, L.; Yan, M.; Sun, W.; Chen, K. Global and Polar Region Temperature Change Induced by Single Mega Volcanic Eruption Based on Community Earth System Model Simulation. Geophys. Res. Lett. 2020, 47, e2020GL089416. [CrossRef]

6. Guillet, S.; Corona, C.; Stoffel, M.; Khodri, M.; Lavigne, F.; Ortega, P.; Eckert, N.; Sielenou, P.D.; Daux, V.; Churakova, O.V.; et al. Climate response to the Samalas volcanic eruption in 1257 revealed by proxy records. Nat. Geosci. 2017, 10, 123-128. [CrossRef]

7. Lavigne, F.; Degeai, J.P.; Komorowski, J.C.; Guillet, S.; Robert, V.; Lahitte, P.; Oppenheimer, C.; Stoffel, M.; Vidal, C.M.; Surono; et al. Source of the great A.D. 1257 mystery eruption unveiled, Samalas volcano, Rinjani Volcanic Complex, Indonesia. Proc. Natl. Acad. Sci. USA 2013, 110, 16742-16747. [CrossRef]

8. Vidal, C.M.; Komorowski, J.-C.; Métrich, N.; Pratomo, I.; Kartadinata, N.; Prambada, O.; Michel, A.; Carazzo, G.; Lavigne, F.; Rodysill, J.; et al. Dynamics of the major plinian eruption of Samalas in 1257 A.D. (Lombok, Indonesia). Bull. Volcanol. 2015, 77, 73. [CrossRef]

9. Vidal, C.M.; Metrich, N.; Komorowski, J.C.; Pratomo, I.; Michel, A.; Kartadinata, N.; Robert, V.; Lavigne, F. The 1257 Samalas eruption (Lombok, Indonesia): The single greatest stratospheric gas release of the Common Era. Sci. Rep. 2016, 6, 34868. [CrossRef]

10. Zhong, Y.; Miller, G.H.; Otto-Bliesner, B.L.; Holland, M.M.; Bailey, D.A.; Schneider, D.P.; Geirsdottir, A. Centennial-scale climate change from decadally-paced explosive volcanism: A coupled sea ice-ocean mechanism. Clim. Dyn. 2010, 37, 2373-2387. [CrossRef]

11. Miller, G.H.; Geirsdóttir, Á.; Zhong, Y.; Larsen, D.J.; Otto-Bliesner, B.L.; Holland, M.M.; Bailey, D.A.; Refsnider, K.A.; Lehman, S.J.; Southon, J.R.; et al. Abrupt onset of the Little Ice Age triggered by volcanism and sustained by sea-ice/ocean feedbacks. Geophys. Res. Lett. 2012, 39, L02708. [CrossRef]

12. Stothers, R.B. Climatic and Demographic Consequences of the Massive Volcanic Eruption of 1258. Clim. Chang. 2000, 45, 361-374. [CrossRef]

13. Stothers, R.B. Volcanic Dry Fogs, Climate Cooling, and Plague Pandemics in Europe and the Middle East. Clim. Chang. 1999, 42, 713-723. [CrossRef]

14. Connell, B.; Gray, J.A.; Redfern, R.; Walker, D. A bioarchaeological study of medieval burials on the site of St Mary Spital: Excavations at Spitalfields Market, London E1, 1991-2007. Mus. Lond. Archaeol. 2012, Monograph Series 60, 1-303. [CrossRef]

15. Robock, A. Volcanic eruptions and climate. Rev. Geophys. 2000, 38, 191-219. [CrossRef] 
16. Driscoll, S.; Bozzo, A.; Gray, L.J.; Robock, A.; Stenchikov, G. Coupled Model Intercomparison Project 5 (CMIP5) simulations of climate following volcanic eruptions. J. Geophys. Res. Atmos. 2012, 117, D17105. [CrossRef]

17. Zanchettin, D.; Timmreck, C.; Bothe, O.; Lorenz, S.J.; Hegerl, G.; Graf, H.-F.; Luterbacher, J.; Jungclaus, J.H. Delayed winter warming: A robust decadal response to strong tropical volcanic eruptions? Geophys. Res. Lett. 2013, 40, 204-209. [CrossRef]

18. Shindell, D.T.; Schmidt, G.A.; Mann, M.E.; Faluvegi, G. Dynamic winter climate response to large tropical volcanic eruptions since 1600. J. Geophys. Res. Atmos. 2004, 109, D05104. [CrossRef]

19. Gao, Y.; Gao, C. European hydroclimate response to volcanic eruptions over the past nine centuries. Int. J. Climatol. 2017, 37, 4146-4157. [CrossRef]

20. Luterbacher, J.; Dietrich, D.; Xoplaki, E.; Grosjean, M.; Wanner, H. European Seasonal and Annual Temperature Variability, Trends, and Extremes Since 1500. Science 2004, 303, 1499-1503. [CrossRef]

21. Neale, R.B.; Richter, J.; Park, S.; Lauritzen, P.H.; Vavrus, S.J.; Rasch, P.J.; Zhang, M. The Mean Climate of the Community Atmosphere Model (CAM4) in Forced SST and Fully Coupled Experiments. J. Clim. 2013, 26, 5150-5168. [CrossRef]

22. Danabasoglu, G.; Bates, S.C.; Briegleb, B.P.; Jayne, S.R.; Jochum, M.; Large, W.G.; Peacock, S.; Yeager, S.G. The CCSM4 Ocean Component. J. Clim. 2012, 25, 1361-1389. [CrossRef]

23. Lawrence, D.M.; Oleson, K.W.; Flanner, M.G.; Fletcher, C.G.; Lawrence, P.J.; Levis, S.; Swenson, S.C.; Bonan, G.B. The CCSM4 Land Simulation, 1850-2005: Assessment of Surface Climate and New Capabilities. J. Clim. 2012, 25, 2240-2260. [CrossRef]

24. Caldeira, K.; Cvijanovic, I. Estimating the Contribution of Sea Ice Response to Climate Sensitivity in a Climate Model. J. Clim. 2014, 27, 8597-8607. [CrossRef]

25. Lehner, F.; Joos, F.; Raible, C.C.; Mignot, J.; Born, A.; Keller, K.M.; Stocker, T.F. Climate and carbon cycle dynamics in a CESM simulation from 850-2100 CE. Earth Syst. Dyn. Discuss. 2015, 6, 351-406. [CrossRef]

26. Otto-Bliesner, B.L.; Brady, E.C.; Fasullo, J.; Jahn, A.; Landrum, L.; Stevenson, S.; Rosenbloom, N.; Mai, A.; Strand, G. Climate Variability and Change since 850 CE: An Ensemble Approach with the Community Earth System Model. Bull. Am. Meteorol. Soc. 2016, 97, 735-754. [CrossRef]

27. Wang, Z.; Li, Y.; Liu, B.; Liu, J. Global climate internal variability in a 2000-year control simulation with Community Earth System Model (CESM). Chin. Geogr. Sci. 2015, 25, 263-273. [CrossRef]

28. Sun, W.; Wang, B.; Liu, J.; Chen, D.; Gao, C.; Ning, L.; Chen, L. How Northern High-Latitude Volcanic Eruptions in Different Seasons Affect ENSO. J. Clim. 2019, 32, 3245-3262. [CrossRef]

29. Sun, W.; Liu, J.; Wang, B.; Chen, D.; Liu, F.; Wang, Z.; Ning, L.; Chen, M. A “La Niña-like” state occurring in the second year after large tropical volcanic eruptions during the past 1500 years. Clim. Dyn. 2019, 52, 7495-7509. [CrossRef]

30. Gao, C.; Robock, A.; Ammann, C. Volcanic forcing of climate over the past 1500 years: An improved ice core-based index for climate models. J. Geophys. Res. Atmos. 2008, 113, D23111. [CrossRef]

31. Cook, E.R.; Seager, R.; Kushnir, Y.; Briffa, K.R.; Büntgen, U.; Frank, D.; Krusic, P.J.; Tegel, W.; van der Schrier, G.; Andreu-Hayles, L.; et al. Old World megadroughts and pluvials during the Common Era. Sci. Adv. 2015, 1, e1500561. [CrossRef]

32. Wells, N.; Goddard, S.; Hayes, M.J. A Self-Calibrating Palmer Drought Severity Index. J. Clim. 2004, 17, 2335-2351. [CrossRef]

33. Zanchettin, D.; Timmreck, C.; Toohey, M.; Jungclaus, J.H.; Bittner, M.; Lorenz, S.J.; Rubino, A. Clarifying the Relative Role of Forcing Uncertainties and Initial-Condition Unknowns in Spreading the Climate Response to Volcanic Eruptions. Geophys. Res. Lett. 2019, 46, 1602-1611. [CrossRef]

34. Fischer, E.M.; Luterbacher, J.; Zorita, E.; Tett, S.F.B.; Casty, C.; Wanner, H. European climate response to tropical volcanic eruptions over the last half millennium. Geophys. Res. Lett. 2007, 34, L05707. [CrossRef]

35. Wegmann, M.; Brönnimann, S.; Bhend, J.; Franke, J.; Folini, D.; Wild, M.; Luterbacher, J. Volcanic Influence on European Summer Precipitation through Monsoons: Possible Cause for "Years without Summer"*. J. Clim. 2014, 27, 3683-3691. [CrossRef]

36. Rao, M.P.; Cook, B.I.; Cook, E.R.; D’Arrigo, R.D.; Krusic, P.J.; Anchukaitis, K.J.; LeGrande, A.N.; Buckley, B.M.; Davi, N.K.; Leland, C.; et al. European and Mediterranean hydroclimate responses to tropical volcanic forcing over the last millennium. Geophys. Res. Lett. 2017, 44, 5104-5112. [CrossRef] 
37. Luterbacher, J.; Werner, J.P.; Smerdon, J.E.; Fernández-Donado, L.; González-Rouco, F.J.; Barriopedro, D.; Ljungqvist, F.C.; Büntgen, U.; Zorita, E.; Wagner, S.; et al. European summer temperatures since Roman times. Environ. Res. Lett. 2016, 11, 024001. [CrossRef]

38. Myhre, G.; Samset, B.H.; Hodnebrog, Ø.; Andrews, T.; Boucher, O.; Faluvegi, G.; Fläschner, D.; Forster, P.M.; Kasoar, M.; Kharin, V.; et al. Sensible heat has significantly affected the global hydrological cycle over the historical period. Nat. Commun. 2018, 9, 1922. [CrossRef]

39. Zambri, B.; Robock, A.; Mills, M.J.; Schmidt, A. Modeling the 1783-1784 Laki Eruption in Iceland: 1. Aerosol Evolution and Global Stratospheric Circulation Impacts. J. Geophys. Res. Atmos. 2019, 124, 6750-6769. [CrossRef]

40. Van Loon, H.; Rogers, J.C. The Seesaw in Winter Temperatures between Greenland and Northern Europe. Part I: General Description. Mon. Weather Rev. 1978, 106, 296-310. [CrossRef]

41. Hurrell, J.W. Decadal Trends in the North Atlantic Oscillation: Regional Temperatures and Precipitation. Science 1995, 269, 676-679. [CrossRef] [PubMed]

42. Trigo, R.M.; Osborn, T.J.; Corte-Real, J.M. The North Atlantic Oscillation influence on Europe: Climate impacts and associated physical mechanisms. Clim. Res. 2002, 20, 9-17. [CrossRef]

43. Folland, C.K.; Knight, J.; Linderholm, H.W.; Fereday, D.; Ineson, S.; Hurrell, J.W. The Summer North Atlantic Oscillation: Past, Present, and Future. J. Clim. 2009, 22, 1082-1103. [CrossRef]

Publisher's Note: MDPI stays neutral with regard to jurisdictional claims in published maps and institutional affiliations. 